\title{
Model of Community Forest Land Management Production and Financial Simulation of Super Teak, Solomon Teak and Sungkai Trees in Samboja Kutai Kartanegara East Kalimantan, Indonesia
}

\author{
Budi Setiawan $^{1,2}$, Abubakar M. Lahjie ${ }^{3}$, Syahrir Yusuf ${ }^{3} \&$ Yosep Ruslim ${ }^{3}$ \\ ${ }^{1}$ Forestry Faculty of Forestry, Tadulako University, Indonesia \\ ${ }^{2}$ Post Graduate Program of Forestry Faculty, Mulawarman University, Indonesia \\ ${ }^{3}$ Faculty of Forestry, Mulawarman University, Indonesia \\ Correspondence: Yosep Ruslim, Faculty of Forestry, Mulawarman University, Jl. Ki Hajar Dewantara PO BOX \\ 1013 Gunung Kelua Samarinda 75116 East Kalimantan, Indonesia Tel: 62-541-735-379. E-mail: \\ yruslim@gmail.com
}

Received: July 12, 2019

Accepted: August 6, 2019

Online Published: September 3, 2019

doi:10.5539/eer.v9n2p48

URL: https://doi.org/10.5539/eer.v9n2p48

\begin{abstract}
The objective of the research were to determine the volume increments, to find out the optimum ages and maximum increment, to know which plant effort was more profitable than each types exploitations, to analyze the financial feasibility and to know the farmers' financial needs and the level of interest by sensitivity analysis. This research was conducted in community forest of Sungai Merdeka Village Km. 38 Samboja District, Kutai Kartanegara Sub District of East Kalimantan Province. The research data was taken based on a purpose sampling system in the research plots of each Model I to V covering an area of 0.25 ha. Model I consisted by super teak 15 years 10x2 m spacing combined with king grass with an interest rate of 5\% resulted in an estimated 6.5-year Pay Back Period (PP); Net Present Value (NPV) Rp. 186,346,058, -; Net Benefit/Cost (B/C) Ratio 3.99; Internal Rate of Return (IRR) 28\%; Equivalent Annual Annuity (EAA) Rp. 12,122,078 and effort scale of 3 ha. Model II consisted by super teak 15 years $10 \times 10 \mathrm{~m}$ spacing with an interest rate of $\%$ produce an estimated 18.5-year PP; Rp. $(15,890,541,-)$ NPV; Net (B/C) Ratio to 0.72 ; (IRR) to 3\%; (EAA) to Rp. $(1,033,703,-)$ and (41) ha effort scale. Model III consisted by Solomon Teak 13 years $10 \times 10 \mathrm{~m}$ spacing with an interest rate of $5 \%$ produce an estimated 10.4 year (PP); (NPV) to Rp. 97,546,242, -; Net (B/C) Ratio to 2.38; (IRR) to 10\%; (EAA) to Rp. $6,345,523,-$ and 7 ha effort scale. Model IV consisted by sungkai 13 years $2 \times 4 \mathrm{~m}$ spacing combined with papaya by an interest rate of 5\% produce an estimated 13.1 years (PP) value; (NPV) to Rp. 41,099,472, -; Net (B/C) Ratio to 1.83; (IRR) to 22.5\%; (EAA) to Rp. 2,673,580, - and 16 ha effort scale. Model V consisted by Sungkai 13 years with an interest rate of 5\% produced an estimated 18.1 year (PP); (NPV) to Rp. -13.141,863, -; Net (B/C) Ratio 0.73; (IRR) to 3.2\%; (EAA) to Rp. -854,897, - and (49) ha effort scale. Its concluded that by $5 \%$ discount factor, Model I, Model III and Model IV were feasible because they have an IRR value higher than Minimum Acceptable Rate (MAR) 5\% and Net B/C Ratio higher than 1. Model II and Model V were not feasible because they have an IRR value lower than MAR 5\% and Net B/C Ratio lower than 1 . The optimum production of all models was reached at the ages of 25 years. The highest MAI was achieved in Model IV of $7.34 \mathrm{~m}^{3} \mathrm{ha}^{-1}$ year ${ }^{-1}$ and the total volume was $183.56 \mathrm{~m}^{3} \mathrm{ha}^{-1}$ year $^{-1}$, while the lowest MAI was achieved in Model II of $6.25 \mathrm{~m}^{3}$ $\mathrm{ha}^{-1}$ year $^{-1}$ and the total volume was $33.10 \mathrm{~m}^{3} \mathrm{ha}^{-1}$ year $^{-1}$. Based on the analysis of effort scale resulted that Model I could be the best choice and most feasible than other because it had the lowest effort scale value, while Model V was the least feasible option to be cultivated because it has the highest scale of effort. Model I, Model III and IV shown the NPV positive value to Rp. 186,346,058, -; Rp.97,546,242, - and Rp.41,099,472, -, while Model II and Model IV shown the negative value of Rp.(15,590,541,-) and Rp.(13,141,863,-).
\end{abstract}

Keywords: community forest, Tectona grandis Linn. f, Peronema canescens Jack, production, financial

\section{Introduction}

Plantations are very important to support forests in the world, including natural resources, and government policies in climate change. Forest capability in meeting carbon needs and forest conservation as well as producing firewood and round wood for industry (Buongiorno et al., 2014). Logging rotation of timber 
companies such as in Laos, which ranges from 10 to 30 years, shows that the optimal age produced by timber cultivation in various types is still not widely known (Wanneng et al., 2014). Height measurement at chest height and total height will increase if the distance is increased. Distance does not have a significant effect on the total production volume and area of the base. The density of the number of plants also takes on an important meaning by increasing the spacing. Characteristics of wood such as ruptured modulus, elastic modulus, tangential compressive strength and tangential shift of grain except tangential to granules are not indicated by an increase in distance (Zahabu et al., 2015). The expansion of agriculture has resulted in large-scale habitat loss, the fragmentation of forests, significant losses in biological diversity and negative impacts on many ecosystem services (Sunderland et al., 2017; Basu, 2014; Iskandar, 2016; Luedeling et al., 2014). Planning management is a major factor in success in forestry development. The national forestry industry plays an important role in the economic and social fields. This is because the volume of production has a significant impact on a forestry concession area (Vanzetti et al., 2018; Mulatu et al., 2016; Ruslim, 2011). Ethiopia has experienced long-term deforestation that has widespread consequences for all aspects of life and human economic activities, but the conventional financial system has not been able to analyze the value of economic sustainability in the development of a country's environment, especially in dealing with the problem of deforestation (Narita et al., 2018; Kupčák, 2012; Siregar et al., 2017). This analysis model can estiamate the potenstial expenditure that will be made in reducing all risks of future (Bernetti et al., 2011; Barkin et al., 2013; Mohammad et al., 2018; Ruslim, 2016). The desire for research on environmental services in an ecosystem has increased in the last three decades, but a deep understanding of the contribution of forests and timber to food production and livelihoods is still limited (Reed et al., 2017; Farshad et al., 2018; Matveev et al., 2018; Dave et al., 2017; Linger, 2014). The approach used in this study is to predict the wood production potential of a forest area for the supply of processing industries, as well as to calculate the estimated financial conditions described in the analysis of internal rate of return (IRR) and net present value (NPV) (Gardingen et al., 2003; Lahjie et al., 2018; Sandalayuk et al., 2019; Winarni, 2017). Teak (Tectona grandis L.f.) is a high-quality commercial wood, categorized as the Verbenaceae tribe. The origin of wood distribution includes India, Myanmar and Thailand. The initial planting carried out in Indonesia began around the 2nd century, by disseminating Hinduism. Teak has been developed by the government, farmers and the private sector up to now. Some development areas are part of which is closely related to the traditional lifestyle of the community. Teak production in Indonesia supports the highest income and welfare of farmers and industries, so that it can support development both locally and nationally. The marketing area is very wide, including domestic and foreign. Harvesting in one high cycle of investment strongly supports environmental sustainability, hydrological systems and local climate (Pramono et al., 2010). Planting was first started from the beginning of the introduction, but the production in various countries is still not accurate (Verhaegen et al., 2010). Teak which has many advantages as forestry plant has been well developed in various regions of Java, while the development in the East Kalimantan region carried out by the public and private sectors results in varied growth differences (Murtinah et al., 2015; Khasanah et al., 2015).

Commercially, the planting of Tectona grandis, which consists of a variety, has always attracted a desire in small-scale production of logs in the tropics, but unfortunately research on its wood character is still very limited (Moya et al., 2011). As a high-quality wood species from the Verbenaceae family, Teak was first brought to Indonesia as naturalized wood species. Excellence as tropical hardwood is very valuable due to strength, straightness, workability, resistance to many pests and diseases and is now known as exotic wood (Jenkins et al., 2002) used for high-quality handicraft industries. Its spread is in almost all tropical regions except desert regions in Africa (Zahabu et al., 2015; Guzmán et al., 2017; Wanneng et al., 2014). Sungkai (Peronema canescens) is a native and local species and one of some commercial trees which has a good prospect to be developed in timber estate in Kalimantan (Wahyudi et al., \& Panjaitan, 2014).

The Purpose of the Community Forest Land Management Model of Super Teak, Solomon and Sungkai Teak Types and Production Simulations in Samboja Kutai Kartanegara, East Kalimantan Indonesia were to know the volume increment of each type of teak and sungkai plant cultivated with agroforestry systems, knowing the optimum ages and maximum increment from each type of teak and sungkai plant that was cultivated so that it could be determined for the needs of the processed wood industry, knowing which plantations were more profitable from each type of teak and sungkai plant cultivated with agroforestry systems, analyzes the financial feasibility of teak and sungkai cultivation with agroforestry system in guaranteeing and improving the livelihood needs of farmers, knowing the farmers' financial needs and the level of interest that could be given to farmers so that it was feasible to be cultivated and get maximum profit and know the resilience of each type of teak and cash crops. i to economic changes carried out by sensitivity analysis. 


\section{Materials and Method}

\subsection{Study Area}

This research was carried out in agroforestry and monoculture community forest owned by Mr. Suwadji Sungai Merdeka Village Km. 38 Samboja District, Kutai Kartanegara District of East Kalimantan Province. The study sites were located in the vicinity of $1^{\circ} 00^{\prime} 04.6^{\prime \prime} \mathrm{S}-116^{\circ} 59^{\prime} 23.1^{\prime \prime} \mathrm{E}$ (Figure 1).
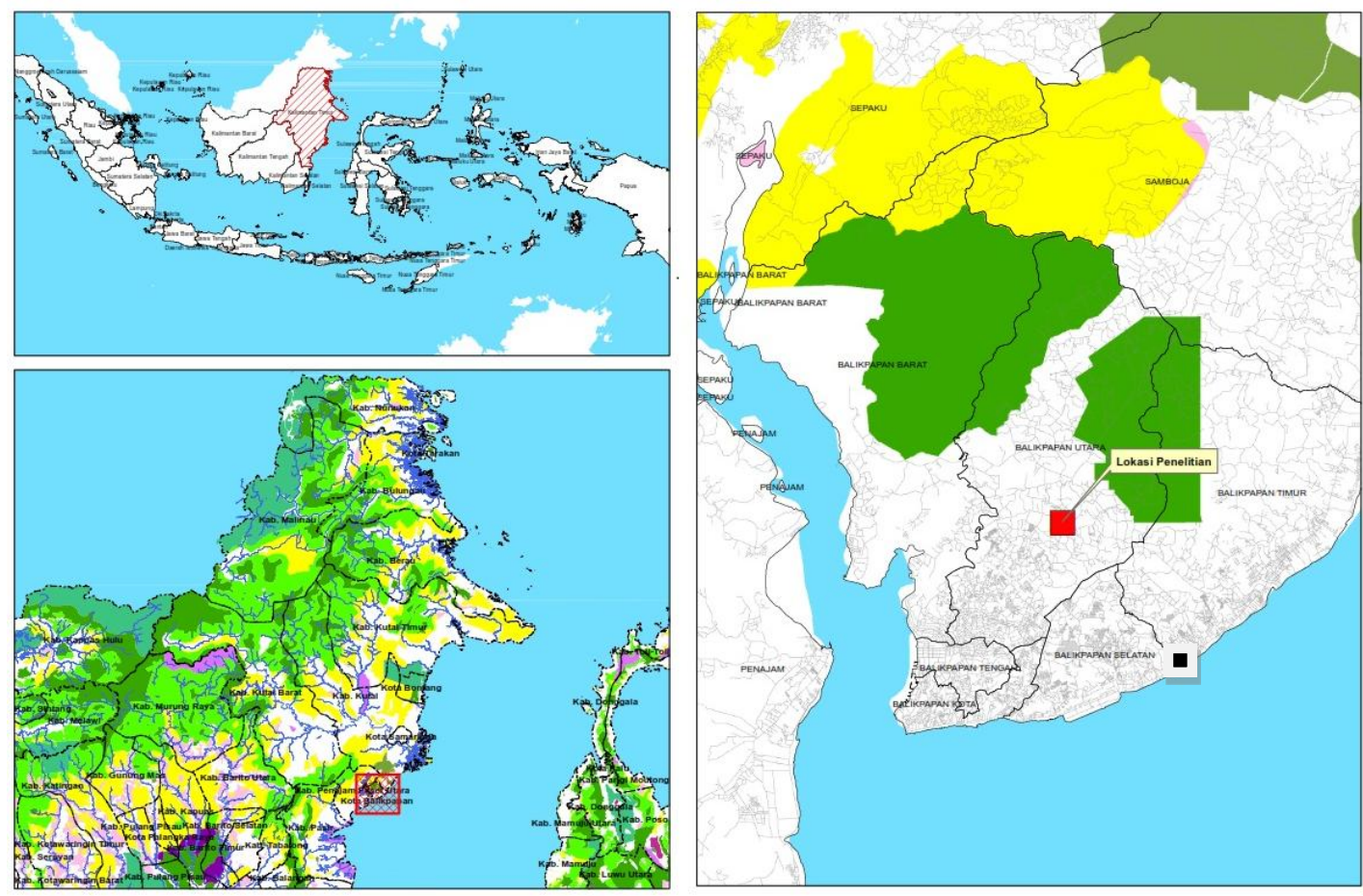

Figure 1. Location studies of Sungai Merdeka Village Km. 38 Samboja District (๘), Kartanegara District of East Kalimantan, Indonesia

\subsection{Data Collection}

The study was conducted for 6 months, namely May 2018 to October 2018, which included research preparation, primary and secondary data collection, data analysis, preparation of reports and presentation. Particularly for preparation and retrieval activities, some secondary data on the general state of the area have been started since April 2008. The research data was taken based on a purpose sampling system on the research plots of each Model I, II, III, IV and V covering an area of 0.25 ha.

Table 1. Land management model with standing composition

\begin{tabular}{cccccc}
\hline Model & Stands (ages) & Spacing $(\mathrm{m})$ & Plot Wides $\left(\mathrm{m}^{2}\right)$ & Population (trees) & Sample (20\%) \\
\hline I & Teak Super dan Grass (15 years) & $10 \times 2$ & 10.000 & 350 & 70 \\
II & Teak Super (15 years) & $10 \times 10$ & 10.000 & 100 & 20 \\
III & Teak Solomon (13 years) & $10 \times 10$ & 10.000 & 68 & 14 \\
IV & Sungkai and Papaya (13 years) & $2 \times 4$ & 10.000 & 860 & 172 \\
V & Sungkai (13 years) & $4 \times 4$ & 10.000 & 450 & 90 \\
\hline
\end{tabular}

\section{Growth/Volume Analysis}

The variables measured within the plots to obtain estimates of the potential production of super teak, solomon teak and sungkai were as follows: Trees Volume, Total Volume, Mean Annual Volume Increment (MAI) and Current Annual Increment (CAI) (Gardingen et al., 2003; Lahjie, 2019).

$$
M A I=\frac{V t}{t}
$$


In which MAI $=$ Mean Annual Increment $\left(\mathrm{m}^{3} \mathrm{ha}^{-1}\right.$ year $\left.^{-1}\right), \mathrm{V}_{\mathrm{t}}=$ total volume at ages $\mathrm{t}\left(\mathrm{m}^{3} \mathrm{ha}^{-1}\right), \mathrm{t}=$ tree ages (in years).

$$
C A I=\frac{V t-V t-1}{n}
$$

In which CAI $=$ Current Annual Increment $\left(\mathrm{m}^{3} \mathrm{ha}^{-1}\right.$ year $\left.{ }^{-1}\right), \mathrm{V}_{\mathrm{t}}=$ Total volume at ages $\mathrm{t}\left(\mathrm{m}^{3} \mathrm{ha}^{-1}\right), \mathrm{Vt}-1=$ Previous total volume $\left(\mathrm{m}^{3} \mathrm{ha}^{-1}\right), \mathrm{T}=$ Second ages minus the first ages (in years)

\section{Results and Discussions}

\subsection{Production Potency of Super Teak and Grass as Model I}

The distance for planting super teak was $10 \mathrm{~m} \times 2 \mathrm{~m}$ with a planting area of 1 ha. The number of seeds planted in the first year of each hectare was $500 \mathrm{ha}^{-1}$. Mathematical distance measurements of stands were to $2,4,8,10,15$, 20,25 and 30 years, respectively. The stands population were to $350 \mathrm{ha}^{-1}$ at the ages of 15 years, so the sample was taken $20 \%$, which was $70 \mathrm{ha}^{-1}$. The estimated stand production cycle was assumed to be 30 years.

Accoording to Table 1 shown that the number of stands decreased naturally and resulted in thinning processes for each increase in ages of stands. The stands population in a row at the ages of 2 years $475 \mathrm{ha}^{-1} ; 4$ years 450 $\mathrm{ha}^{-1}$; ages 8 years $410 \mathrm{ha}^{-1} ; 10$ years $380 \mathrm{ha}^{-1}$; ages 15 years $350 \mathrm{ha}^{-1}$ and ages 20 years $320 \mathrm{ha}^{-1}$. The averages diameter of stands were at 2, 4, 8, 15 and 20 years respectively $6.5 \mathrm{~cm} ; 9.2 \mathrm{~cm} ; 14.5 \mathrm{~cm} ; 17.3 \mathrm{~cm} ; 24.3 \mathrm{~cm}$ and $7.0 \mathrm{~cm}$. The diameter distribution at the ages of 25 years ranged between $30 \mathrm{~cm}$ and $39 \mathrm{~cm}$ with the most frequent diameter of $35 \mathrm{~cm}$. Branch free height on averages at 2, 4, 8, 15 and 20 years respectively $2.4 \mathrm{~cm} ; 3.3$ $\mathrm{cm} ; 5.0 \mathrm{~cm} ; 5.6 \mathrm{~cm} ; 6.5 \mathrm{~cm}$ and $7.0 \mathrm{~cm}$.

The comparison of the growth resulted between the averages annual increment (MAI) and the current annual increment (CAI) shown the lowest difference of $0.29 \mathrm{~m}^{3} \mathrm{ha}^{-1} \mathrm{year}^{-1}$, so that the optimum production of stands was at 25 years with an averages volume of each tree $0.539 \mathrm{~m}^{3}$; the averages diameter of each tree was $35.2 \mathrm{~cm}$ and branch-free height averages $7.1 \mathrm{~m}$. The total stand volume at the ages of 25 years was $156.21 \mathrm{~m}^{3} \mathrm{ha}^{-1} \mathrm{year}^{-1}$, while the averages annual increment (MAI) at the ages of 25 was $6.25 \mathrm{~m}^{3} \mathrm{ha}^{-1}$ year ${ }^{-1}$ and current annual increment (CAI) was $6.54 \mathrm{~m}^{3} \mathrm{ha}^{-1}$ year $^{-1}$. The reduction in the number of trees increased the averages annual increment (MAI) to the 25 years stand of $6.25 \mathrm{~m} \mathrm{ha}^{3} \mathrm{year}^{-1}$, but was less influential at later ages, shown in the 30 years stand to be $5.77 \mathrm{~m}^{3} \mathrm{ha}^{-1}$ year- 1 .

Figure 1 shown clearly that the intersection point between MAI and CAI occurred in 25 years stands. This meant that at the ages of 25 stands were ready to be harvested with a total production volume of $156.21 \mathrm{~m}^{3} \mathrm{ha}^{-1}$ year .

Table 2. Potential production of super teak stands and king grass with $10 \mathrm{~m}$ × $2 \mathrm{~m}$ spacing as Model I

\begin{tabular}{cccccccccccccc}
\hline Ages & $\mathrm{N}$ & $\mathrm{D}$ & $\mathrm{H}$ & $\mathrm{F}$ & $\mathrm{V}$ & $\mathrm{Vt}$ & $\mathrm{MAI}$ & $\mathrm{CAI}$ & $\mathrm{PJ}$ & $\mathrm{TPtot}$ & MAI $_{\text {tot }}$ & CAI $_{\text {tot }}$ & $\mathrm{K}$ \\
\hline & 475 & 6.5 & 24 & 0.72 & 0.006 & 2.72 & 1.36 & - & 0.00 & 2.72 & 1.36 & - & 0.369 \\
4 & 450 & 9.2 & 33 & 0.73 & 0.016 & 7.20 & 1.80 & 2.24 & 0.14 & 7.35 & 1.84 & 2.31 & 0.359 \\
8 & 410 & 14.5 & 5.0 & 0.74 & 0.061 & 25.04 & 3.13 & 4.46 & 0.64 & 25.68 & 3.21 & 4.58 & 0.345 \\
10 & 380 & 17.3 & 5.6 & 0.75 & 0.099 & 37.50 & 3.75 & 6.23 & 1.83 & 39.33 & 3.93 & 6.83 & 0.324 \\
15 & 350 & 24.3 & 6.5 & 0.76 & 0.229 & 80.15 & 5.34 & 8.53 & 2.96 & 83.11 & 5.54 & 8.76 & 0.267 \\
20 & 320 & 30.2 & 7.0 & 0.77 & 0.386 & 123.49 & 6.17 & 8.67 & 6.87 & 130.36 & 6.52 & 9.45 & 0.232 \\
25 & 290 & 35.2 & 7.1 & 0.78 & 0.539 & 156.21 & 6.25 & 6.54 & 11.58 & 167.79 & 6.71 & 7.49 & 0.202 \\
30 & 240 & 39.9 & 7.3 & 0.79 & 0.721 & 172.97 & 5.77 & 3.35 & 26.93 & 199.90 & 6.66 & 6.42 & 0.183 \\
\hline
\end{tabular}

Note. N: Population of Super Teak (trees ha); D: Tree Diameter $(\mathrm{cm})$; H: Branch-free Height (m); Vt: Total Volume $\left(\mathrm{m}^{3} \mathrm{ha}^{-1}\right)$; MAI: Mean Annual Increment $\left(\mathrm{m}^{3} \mathrm{ha}^{-1}\right.$ year $\left.^{-1}\right)$; CAI: Current Annual Increment $\left(\mathrm{m}^{3} \mathrm{ha}^{-1} \mathrm{year}^{-1}\right)$.

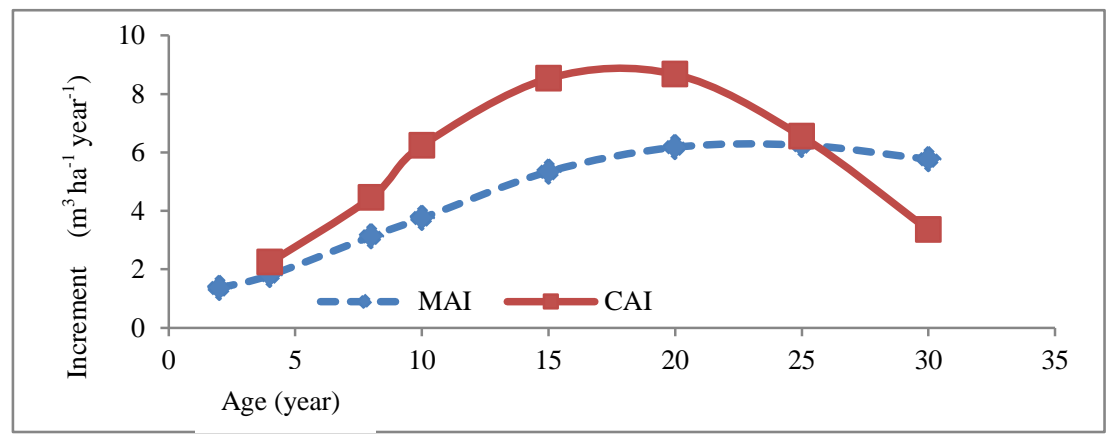

Figure 1. Intersection between MAI and CAI occured at the age of 25 years stand of Model I 


\subsection{Potential of Super Teak Production as Model II}

The distance for planting super teak was $10 \mathrm{~m} \times 10 \mathrm{~m}$ with a planting area of 1 ha. The number of seeds planted in the first year of each ha was $100 \mathrm{ha}^{-1}$. Mathematical distance measurements of stands were to 2, 4, 8, 10, 15, 20,25 and 30 years, respectively. The total population of 15 years stands was $75 \mathrm{ha}^{-1}$, so the sample was taken $20 \%$, which was $20 \mathrm{ha}^{-1}$. The estimated stand production cycle was assumed to be 30 years.

According to Table 2 shown that the number of stands decreased naturally and resulted in thinning processing for each increasing in ages of stands. The stands population were at 2 years $95 \mathrm{ha}^{-1}$; ages 4 years $90 \mathrm{ha}^{-1}$; ages 8 years $87 \mathrm{ha}^{-1}$; ages 10 years $75 \mathrm{ha}^{-1}$; ages 15 years $70 \mathrm{ha}^{-1}$ and ages 20 years $65 \mathrm{ha}^{-1}$. The averages diameter of stands were at 2, 4, 8, 15 and 20 years was $2.5 \mathrm{~cm}$ respectively; $3.5 \mathrm{~cm} ; 5.2 \mathrm{~cm} ; 5.8 \mathrm{~cm} ; 6.8 \mathrm{~cm}$ and $7.3 \mathrm{~cm}$. The diameter distribution at the ages of 25 years ranged between $30 \mathrm{~cm}$ and $40 \mathrm{~cm}$ with the most frequent diameter of $36 \mathrm{~cm}$. Branch free height on averages at 2, 4, 8, 15 and 20 years respectively were to $2.5 \mathrm{~cm} ; 3.5 \mathrm{~cm} ; 5.2 \mathrm{~cm}$; $5.8 \mathrm{~cm} ; 6.8 \mathrm{~cm}$ and $7.3 \mathrm{~cm}$.

The comparison of the growth resulted between the averages annual increment (MAI) and the current annual increment (CAI) shown that the lowest difference was $0.00 \mathrm{~m}^{3} \mathrm{ha}^{-1}$ year $^{-1}$, so the optimum production of stands was at 25 years with the averages volume of each tree $0.602 \mathrm{~m}^{3}$; the averages diameter of each tree was to 36.2 $\mathrm{cm}$ and the branch-free height was on averages $7.5 \mathrm{~m}$. The total stand volume at the ages of 25 was $33.10 \mathrm{~m}^{3} \mathrm{ha}^{-1}$ year ${ }^{-1}$, while the averages annual increment (MAI) at the ages of 25 was $1.32 \mathrm{~m}^{3} \mathrm{ha}^{-1}$ year $^{-1}$ and the current annual increment (CAI) was $1.32 \mathrm{~m}^{3} \mathrm{ha}^{-1}$ year $^{-1}$. The reduction in the number of trees increased the averages annual increment (MAI) to the 25 years stand of $1.32 \mathrm{~m}^{3} \mathrm{ha}^{-1}$ year $^{-1}$, but was less influential at later ages, shown in the 30 years stand to be $1.29 \mathrm{~m}^{3} \mathrm{ha}^{-1}$ year ${ }^{-1}$.

Based on Figure 2 shown clearly that the intersection point between MAI and CAI occurred in 25 years stands. This meant that the ages of 25 years was ready to be harvested with a total production volume of $33.10 \mathrm{~m}^{3} \mathrm{ha}^{-1}$ year $^{-1}$.

Table 2. Potential of super teak stand production with spacing planting of $10 \mathrm{~m} \times 10 \mathrm{~m}$ as Model II

\begin{tabular}{cccccccccccccc}
\hline Ages & $\mathrm{N}$ & $\mathrm{D}$ & $\mathrm{H}$ & $\mathrm{F}$ & $\mathrm{V}$ & $\mathrm{Vt}$ & $\mathrm{MAI}$ & $\mathrm{CAI}$ & $\mathrm{PJ}$ & $\mathrm{TPtot}$ & MAI $_{\text {tot }}$ & CAI $_{\text {tot }}$ & $\mathrm{K}^{2}$ \\
\hline 2 & 95 & 7.0 & 2.5 & 0.72 & 0.007 & 0.66 & 0.33 & - & 0.00 & 0.66 & 0.33 & - & 0.357 \\
4 & 90 & 10.0 & 3.5 & 0.73 & 0.020 & 1.81 & 0.45 & 057 & 0.03 & 1.84 & 0.46 & 0.59 & 0.350 \\
8 & 87 & 15.1 & 5.2 & 0.74 & 0.069 & 5.99 & 0.75 & 1.05 & 0.06 & 6.05 & 0.76 & 1.05 & 0.344 \\
10 & 75 & 18.7 & 5.8 & 0.75 & 0.119 & 8.96 & 0.90 & 1.48 & 0.83 & 9.78 & 0.98 & 1.87 & 0.310 \\
15 & 70 & 25.0 & 6.8 & 0.76 & 0.254 & 17.75 & 1.18 & 1.76 & 0.60 & 18.35 & 1.22 & 1.71 & 0.272 \\
20 & 65 & 30.4 & 7.3 & 0.77 & 0.408 & 26.51 & 1.33 & 1.75 & 1.27 & 27.77 & 1.39 & 1.89 & 0.240 \\
25 & 55 & 36.2 & 7.5 & 0.78 & 0.602 & 33.10 & 1.32 & 1.32 & 4.08 & 37.18 & 1.49 & 1.88 & 0.207 \\
30 & 50 & 40.3 & 7.7 & 0.79 & 0.776 & 38.78 & 1.29 & 1.14 & 3.01 & 41.79 & 1.39 & 0.92 & 0.191 \\
\hline
\end{tabular}

Note. N: Population of Super Teak (trees ha); D: Tree Diameter $(\mathrm{cm})$; H: Branch-free Height (m); Vt: Total Volume $\left(\mathrm{m}^{3} \mathrm{ha}^{-1}\right)$; MAI: Mean Annual Increment $\left(\mathrm{m}^{3} \mathrm{ha}^{-1}\right.$ year $\left.^{-1}\right)$; CAI: Current Annual Increment $\left(\mathrm{m}^{3} \mathrm{ha}^{-1} \mathrm{year}^{-1}\right)$.

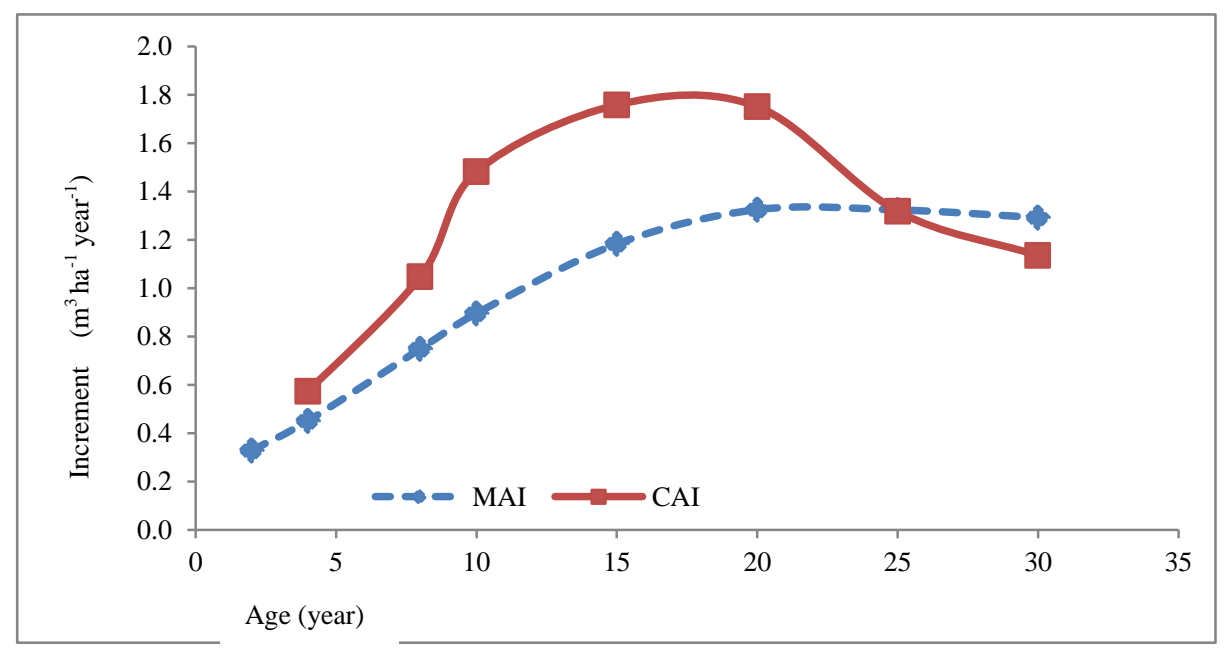

Figure 2. Intersection point between MAI and CAI occured in 25 years stands of Model II 


\subsection{Solomon Teak Production Potential as Model III}

The distance of planting Solomon teak was $10 \mathrm{~m}$ x $10 \mathrm{~m}$ with a planting area of 1 ha. The number of seeds planted in the first year of each ha was $100 \mathrm{ha}^{-1}$. Mathematical distance measurements of stands were to 2, 4, 8, $10,15,20,25$ and 30 years, respectively. The total population of 13 years stands was 68 ha $^{-1}$, so the sample was taken $20 \%$, which was equal to $14 \mathrm{ha}^{-1}$. The estimated stand production cycle was assumed to be 30 years.

Based on Table 3 shown that the number of stands decreased naturally and resulted in thinning process for each increasing in stands ages. The stands population were at 2 years $95 \mathrm{ha}^{-1}$; ages 4 years $87 \mathrm{ha}^{-1}$; ages 8 years 80 ha $^{-1}$; ages 10 years $72 \mathrm{ha}^{-1}$; ages 15 years $68 \mathrm{ha}^{-1}$ and ages 20 years $65 \mathrm{ha}^{-1}$. The averages diameter of stands at 2, 4, 8, 15 and 20 consecutive years was $9.8 \mathrm{~cm} ; 14.5 \mathrm{~cm} ; 25.5 \mathrm{~cm} ; 31.4 \mathrm{~cm} ; 40.5 \mathrm{~cm}$ and $46.8 \mathrm{~cm}$. The diameter distribution at the ages of 25 years ranged from $46 \mathrm{~cm}$ and $54 \mathrm{~cm}$ with the most frequent diameter of $51 \mathrm{~cm}$. Branch free height on averages were to $2,4,8,15$ and 20 years respectively $6.5 \mathrm{~cm} ; 7.5 \mathrm{~cm} ; 8.6 \mathrm{~cm} ; 9.0 \mathrm{~cm} ; 10.5$ $\mathrm{cm}$ and $11.8 \mathrm{~cm}$.

Comparison of the growth resulted between the averages annual increment (MAI) and the current annual increment (CAI) shown the lowest difference of $0.04 \mathrm{~m}^{3} \mathrm{ha}^{-1}$ year ${ }^{-1}$, so that the optimum production of stands at 25 years with the averages volume of each tree $2.111 \mathrm{~m}^{3}$; the averages diameter of each tree was to $51.7 \mathrm{~cm}$ and the branch height was an averages of $12.9 \mathrm{~m}$. The total stand volume at the ages of 25 years was $126.67 \mathrm{~m}^{3} \mathrm{ha}^{-1}$ year $^{-1}$, while the averages annual increment (MAI) at the ages of 25 was to $5.07 \mathrm{~m}^{3} \mathrm{ha}^{-1}$ year $^{-1}$ and the current annual increment (CAI) was $5.03 \mathrm{~m}^{3} \mathrm{ha}^{-1}$ year $^{-1}$. The reduction in the number of trees increased the averages annual increment (MAI) to the 25 years stand of $5.07 \mathrm{~m}^{3} \mathrm{ha}^{-1}$ year ${ }^{-1}$, but was less influential at the next ages, shown in the 30 years stand to be $4.68 \mathrm{~m}^{3} \mathrm{ha}^{-1}$ year $^{-1}$.

Based on Figure 3 shown clearly that the intersection point between MAI and CAI occurred in 25 years stands. This meant that the ages of 25 stands was ready to be harvested with a total production volume of $126.67 \mathrm{~m}^{3} \mathrm{ha}^{-1}$ year $^{-1}$.

Table 3. Potential production of solomon teak stands with spacing of $10 \mathrm{~m}$ x $10 \mathrm{~m}$ as Model III

\begin{tabular}{cccccccccccccc}
\hline Ages & $\mathrm{N}$ & $\mathrm{D}$ & $\mathrm{H}$ & $\mathrm{F}$ & $\mathrm{V}$ & $\mathrm{Vt}$ & $\mathrm{MAI}$ & $\mathrm{CAI}$ & $\mathrm{PJ}$ & $\mathrm{TPtot}$ & MAI $_{\text {tot }}$ & $\mathrm{CAI}_{\text {tot }}$ & $\mathrm{K}$ \\
\hline 2 & 95 & 9.8 & 6.5 & 0.72 & 0.035 & 3.35 & 1.68 & - & 0.00 & 3.35 & 1.68 & - & 0.663 \\
4 & 87 & 14.5 & 7.5 & 0.73 & 0.090 & 7.86 & 1.97 & 2.25 & 0.28 & 8.14 & 2.04 & 2.40 & 0.517 \\
8 & 80 & 25.5 & 8.6 & 0.74 & 0.325 & 25.99 & 3.25 & 4.53 & 0.63 & 26.62 & 3.33 & 4.62 & 0.337 \\
10 & 72 & 31.4 & 9.0 & 0.75 & 0.522 & 37.62 & 3.76 & 5.81 & 2.60 & 40.21 & 4.02 & 6.80 & 0.287 \\
15 & 68 & 40.5 & 10.5 & 0.76 & 1.028 & 69.87 & 4.66 & 6.45 & 2.09 & 71.96 & 4.80 & 6.35 & 0.259 \\
20 & 65 & 46.8 & 11.8 & 0.77 & 1.562 & 101.54 & 5.08 & 6.33 & 3.08 & 104.62 & 5.23 & 6.53 & 0.252 \\
25 & 60 & 51.7 & 12.9 & 0.78 & 2.111 & 126.67 & 5.07 & 5.03 & 7.81 & 134.48 & 5.38 & 5.97 & 0.250 \\
30 & 55 & 54.6 & 13.8 & 0.79 & 2.551 & 140.32 & 4.68 & 2.73 & 10.56 & 150.88 & 5.03 & 3.28 & 0.253 \\
\hline
\end{tabular}

Note. N: Population of Solomon Teak (trees ha); D: Tree Diameter $(\mathrm{cm})$; H: Branch-free Height $(\mathrm{m})$; Vt: Total Volume $\left(\mathrm{m}^{3} \mathrm{ha}^{-1}\right)$; MAI: Mean Annual Increment $\left(\mathrm{m}^{3} \mathrm{ha}^{-1}\right.$ year $\left.^{-1}\right)$; CAI: Current Annual Increment $\left(\mathrm{m}^{3} \mathrm{ha}^{-1}\right.$ year $\left.^{-1}\right)$.

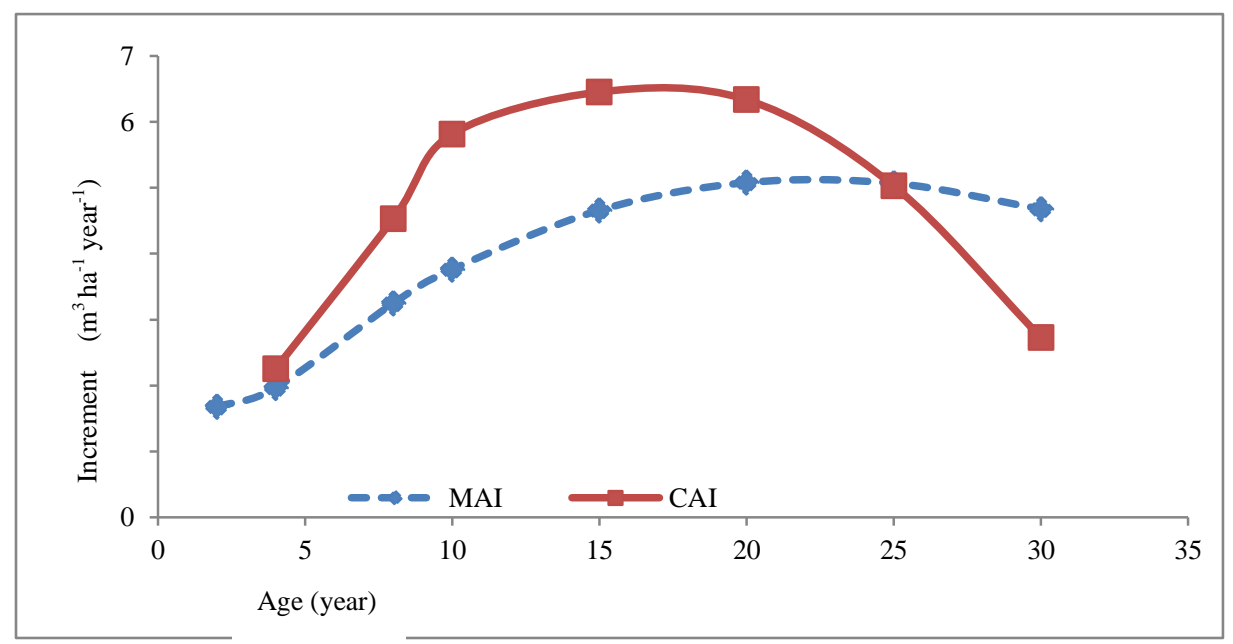

Figure 3. Intersection point between MAI and CAI occured in 25 years stands of Model III 


\subsection{Potential of Sungkai Production with Papaya as Model IV}

The planting distance of Sungkai was $4 \mathrm{~m} \times 2 \mathrm{~m}$ with a planting area of 1 ha. The number of seeds planted in the first year of each ha was $1250 \mathrm{ha}^{-1}$. Mathematical distance measurements of stands were to 2, 4, 8, 10, 15, 20, 25 and 30 years, respectively. The total population of 13 years stands was $860 \mathrm{ha}^{-1}$, so the sample was taken $20 \%$ which was equal to $172 \mathrm{ha}^{-1}$. The estimated stand production cycle was assumed to be 30 years.

According to Table 4 shown that the number of stands decreased naturally and resulted in thinning processes for each ages increase in stands. The stands population at the ages of 2 years $1180 \mathrm{ha}^{-1}$; ages 4 years $1090 \mathrm{ha}^{-1} ; 8$ years $1000 \mathrm{ha}^{-1}$; ages 10 years $900 \mathrm{ha}^{-1}$; ages 15 years $860 \mathrm{ha}^{-1}$ and ages $20820 \mathrm{ha}^{-1}$. The averages diameter of stands at 2, 4, 8, 15 and 20 years respectively $4.7 \mathrm{~cm} ; 7.0 \mathrm{~cm} ; 11.5 \mathrm{~cm} ; 12.8 \mathrm{~cm} ; 16.9 \mathrm{~cm}$ and $19.9 \mathrm{~cm}$. The diameter distribution at the ages of 25 years ranged between $19 \mathrm{~cm}$ and $25 \mathrm{~cm}$ with the most frequent diameter of $22 \mathrm{~cm}$. Branch free height on averages at 2, 4, 8, 15 and 20 years respectively $3.1 \mathrm{~cm} ; 4.0 \mathrm{~cm} ; 4.8 \mathrm{~cm} ; 5.9 \mathrm{~cm}$; $6.7 \mathrm{~cm}$ and $7.5 \mathrm{~cm}$.

Comparison of the growth resulted between the averages annual increment (MAI) and the current annual increment (CAI) shown the lowest difference of $0.07 \mathrm{~m}^{3} \mathrm{ha}^{-1} \mathrm{year}^{-1}$, so that the optimum production of stands at 25 years with the averages volume of each tree $0.251 \mathrm{~m}^{3}$; the averages diameter of each tree was $22.8 \mathrm{~cm}$ and the branch-free height was $7.9 \mathrm{~m}$ on averages. The total stand volume at the ages of 25 years was $183.56 \mathrm{~m}^{3} \mathrm{ha}^{-1}$ year ${ }^{-1}$, while the averages annual increment (MAI) at the ages of 25 years was $7.34 \mathrm{~m}^{3} \mathrm{ha}^{-1}$ year ${ }^{-1}$ and the current annual increment (CAI) was $7.27 \mathrm{~m}^{3} \mathrm{ha}^{-1} \mathrm{year}^{-1}$. The reduction in the number of trees increased the averages annual increment (MAI) to the 25 years stand of $7.34 \mathrm{~m}^{3} \mathrm{ha}^{-1}$ year ${ }^{-1}$, but was less influential at later ages, indicated in the 30 years stand to be $6.40 \mathrm{~m}^{3} \mathrm{ha}^{-1}$ year $^{-1}$.

Based on Figure 4 shown clearly that the intersection point between MAI and CAI occurred in 25 years stands. This meant that the ages of 25 years was ready to be harvested with a total production volume of $183.56 \mathrm{~m}^{3} \mathrm{ha}^{-1}$ year ${ }^{-1}$.

Table 4. Potential Production of Sungkai and Papaya Stands with Planting Spaces of $4 \mathrm{~m}$ x $2 \mathrm{~m}$ as Model IV

\begin{tabular}{cccccccccccccc}
\hline Ages & $\mathrm{N}$ & $\mathrm{D}$ & $\mathrm{H}$ & $\mathrm{F}$ & $\mathrm{V}$ & $\mathrm{Vt}$ & $\mathrm{MAI}_{\text {st }}$ & $\mathrm{CAI}_{\mathrm{st}}$ & $\mathrm{PJ}$ & $\mathrm{TPtot}$ & MAI $_{\text {tot }}$ & $\mathrm{CAI}_{\text {tot }}$ & $\mathrm{K}$ \\
\hline 2 & 1180 & 4.7 & 3.1 & 0.72 & 0.004 & 4.57 & 2.28 & - & 0.00 & 4.57 & 2.28 & - & 0.660 \\
4 & 1090 & 7.0 & 4.0 & 0.73 & 0.011 & 12.24 & 3.06 & 3.84 & 0.35 & 12.59 & 3.15 & 4.01 & 0.571 \\
8 & 1000 & 11.5 & 4.8 & 0.74 & 0.037 & 36.88 & 4.61 & 6.16 & 1.01 & 37.89 & 4.74 & 6.32 & 0.417 \\
10 & 900 & 12.8 & 5.9 & 0.75 & 0.057 & 51.22 & 5.12 & 7.17 & 3.69 & 54.91 & 5.49 & 8.51 & 0.461 \\
15 & 860 & 16.9 & 6.7 & 0.76 & 0.114 & 98.18 & 6.55 & 9.39 & 2.28 & 100.46 & 6.70 & 9.11 & 0.396 \\
20 & 820 & 19.9 & 7.5 & 0.77 & 0.180 & 147.21 & 7.36 & 9.81 & 4.57 & 151.78 & 7.59 & 10.26 & 0.377 \\
25 & 730 & 22.8 & 7.9 & 0.78 & 0.251 & 183.56 & 7.34 & 7.27 & 16.16 & 199.72 & 7.99 & 9.59 & 0.346 \\
30 & 560 & 25.5 & 8.5 & 0.79 & 0.343 & 191.95 & 6.40 & 1.68 & 42.75 & 234.70 & 7.82 & 7.00 & 0.333 \\
\hline
\end{tabular}

Note. N: Population of sungkai(trees ha); D: Tree Diameter $(\mathrm{cm})$; H: Branch-free Height $(\mathrm{m})$; Vt: Total Volume $\left(\mathrm{m}^{3} \mathrm{ha}^{-1}\right)$; MAI: Mean Annual Increment $\left(\mathrm{m}^{3} \mathrm{ha}^{-1}\right.$ year $\left.^{-1}\right)$; CAI: Current Annual Increment $\left(\mathrm{m}^{3} \mathrm{ha}^{-1}\right.$ year $\left.^{-1}\right)$.

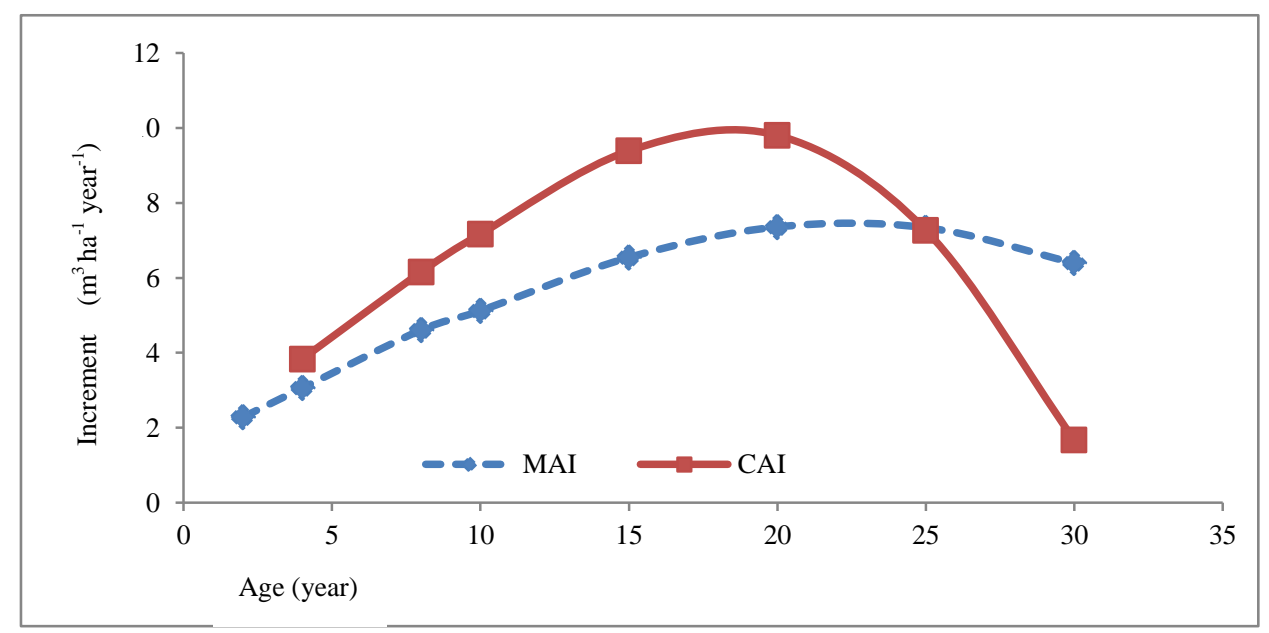

Figure 4. Intersection point between MAI and CAI occured in 25 years stands of Model IV 


\subsection{Sungkai Production Potential as Model V}

The planting distance of Sungkai was $4 \mathrm{~m} \mathrm{x} 4 \mathrm{~m}$ with a planting area of 1 ha. The number of seeds planted in the first year of each ha was $625 \mathrm{ha}^{-1}$. Mathematical distance measurements of stands were to 2, 4, 8, 10, 15, 20, 25 and 30 years, respectively. The total population of 13 years stands was $450 \mathrm{ha}^{-1}$, so the sample was taken $20 \%$, which was equal to $90 \mathrm{ha}^{-1}$. The estimated stand production cycle was assumed to be 30 years.

Table 5 showns that the number of stands decreased naturally and resulted in thinning processes for each increase in ages of stands. Population of consecutive stands at 2 years $595 \mathrm{ha}^{-1}$; ages 4 years $560 \mathrm{ha}^{-1} ; 8$ years $500 \mathrm{ha}^{-1}$; ages 10 years $470 \mathrm{ha}^{-1}$; ages 15 years $450 \mathrm{ha}^{-1}$ and ages 20 years 430 ha-1. The averages diameter of stands at 2, 4, 8, 15 and 20 years respectively $5.2 \mathrm{~cm} ; 7.5 \mathrm{~cm} ; 12.2 \mathrm{~cm} ; 13.4 \mathrm{~cm} ; 17.6 \mathrm{~cm}$ and $20.5 \mathrm{~cm}$. The diameter distribution at the ages of 25 years ranged between $20 \mathrm{~cm}$ and $26 \mathrm{~cm}$ with the most frequent diameter of $23 \mathrm{~cm}$. Branch-free height on averages at 2, 4, 8, 15 and 20 years respectively $3.2 \mathrm{~cm} ; 4.4 \mathrm{~cm} ; 5.0 \mathrm{~cm} ; 6.0 \mathrm{~cm}$; $7.0 \mathrm{~cm}$ and $8.0 \mathrm{~cm}$.

The comparison of the growth resulted between the averages annual increment (MAI) and the current annual increment (CAI) shown the lowest difference of $0.14 \mathrm{~m}^{3} \mathrm{ha}^{-1} \mathrm{year}^{-1}$, so that the optimum production of stands at 25 years with an averages volume of each tree $0.275 \mathrm{~m}^{3}$; the averages diameter of each tree was $23.0 \mathrm{~cm}$ and the branch height was an averages of $8.5 \mathrm{~m}$. The total stand volume at the ages of 25 years was $110.13 \mathrm{~m}^{3} \mathrm{ha}^{-1} \mathrm{year}^{-1}$, while the averages annual increment (MAI) at the ages of 25 was $4.41 \mathrm{~m}^{3} \mathrm{ha}^{-1}$ year ${ }^{-1}$ and the current annual increment (CAI) was $4.55 \mathrm{~m}^{3} \mathrm{ha}^{-1} \mathrm{year}^{-1}$. The reduction in the number of trees increased the averages annual increment (MAI) to the 25 years stand of $4.41 \mathrm{~m}^{3} \mathrm{ha}^{-1}$ year $^{-1}$, but was less influential at later ages, indicated in the 30 years stand to be $4.13 \mathrm{~m}^{3} \mathrm{ha}^{-1} \mathrm{year}^{-1}$.

Figure 5 showns clearly that the intersection point between MAI and CAI occurred in 25 years stands. This meant that the ages of 25 stands was ready to be harvested with a total production volume of $110.13 \mathrm{~m}^{3} \mathrm{ha}^{-1}$ year ${ }^{-1}$.

Table 5. Potential of sungkai stand production with $4 \mathrm{~m} \times 4 \mathrm{~m}$ spacing distance as Model V

\begin{tabular}{cccccccccccccc}
\hline Ages & $\mathrm{N}$ & $\mathrm{D}$ & $\mathrm{H}$ & $\mathrm{F}$ & $\mathrm{V}$ & $\mathrm{Vt}$ & $\mathrm{MAI}_{\text {st }}$ & $\mathrm{CAI}_{\text {st }}$ & $\mathrm{PJ}$ & $\mathrm{TPtot}$ & MAI $_{\text {tot }}$ & CAI $_{\text {tot }}$ & $\mathrm{K}$ \\
\hline 2 & 595 & 5.0 & 3.2 & 0.72 & 0.005 & 2.69 & 1.35 & - & 0.00 & 2.69 & 1.35 & - & 0.640 \\
4 & 560 & 7.5 & 4.4 & 0.73 & 0.014 & 7.94 & 1.99 & 2.63 & 0.16 & 8.10 & 2.03 & 2.71 & 0.587 \\
8 & 500 & 12.2 & 5.0 & 0.74 & 0.043 & 21.62 & 2.70 & 3.42 & 0.85 & 22.47 & 2.81 & 3.59 & 0.410 \\
10 & 470 & 13.4 & 6.0 & 0.75 & 0.063 & 29.81 & 2.98 & 4.10 & 1.30 & 31.11 & 3.11 & 4.32 & 0.448 \\
15 & 450 & 17.6 & 7.0 & 0.76 & 0.129 & 58.21 & 3.88 & 5.68 & 1.27 & 59.48 & 3.97 & 5.67 & 0.398 \\
20 & 430 & 20.5 & 8.0 & 0.77 & 0.203 & 87.38 & 4.37 & 5.83 & 2.59 & 89.97 & 4.50 & 6.10 & 0.390 \\
25 & 400 & 23.0 & 8.5 & 0.78 & 0.275 & 110.13 & 4.41 & 4.55 & 6.10 & 116.22 & 4.65 & 5.25 & 0.370 \\
30 & 340 & 26.0 & 8.7 & 0.79 & 0.365 & 124.01 & 4.13 & 2.78 & 16.52 & 140.52 & 4.68 & 4.86 & 0.335 \\
\hline
\end{tabular}

Note. N: Population of sungkai (trees ha); D: Tree Diameter (cm); H: Branch-free Height (m); Vt: Total Volume ( $\left.\mathrm{m}^{3} \mathrm{ha}^{-1}\right)$; MAI: Mean Annual Increment $\left(\mathrm{m}^{3} \mathrm{ha}^{-1}\right.$ year $\left.^{-1}\right)$; CAI: Current Annual Increment $\left(\mathrm{m}^{3} \mathrm{ha}^{-1}\right.$ year $\left.^{-1}\right)$.

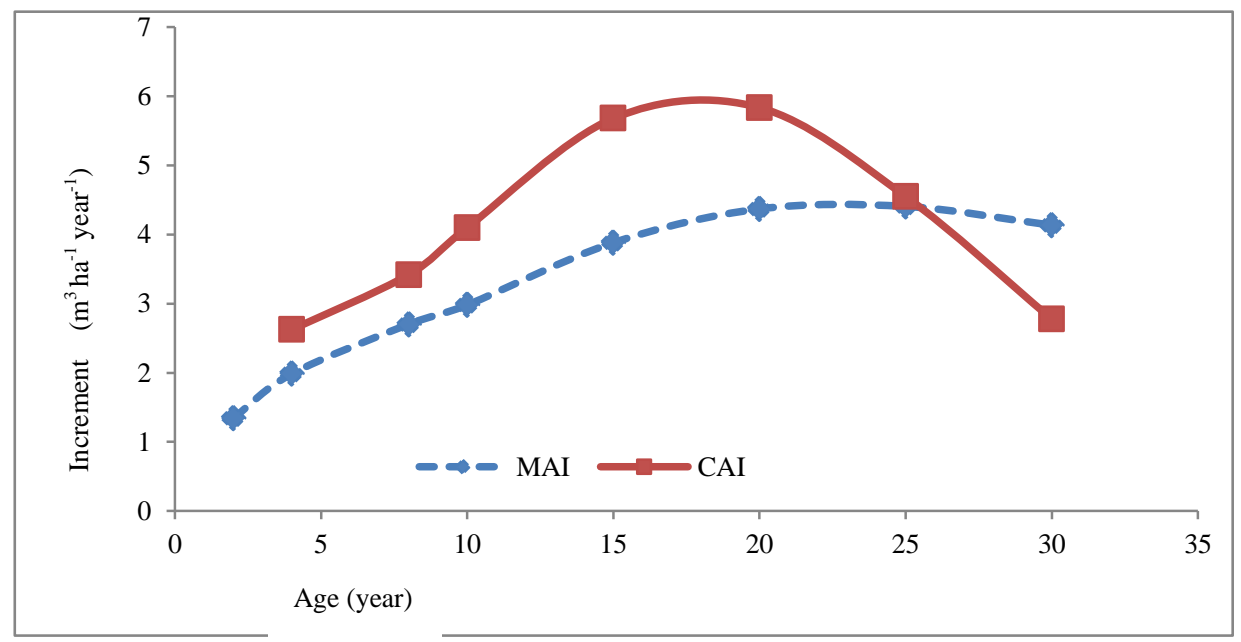

Figure 5. Intersection point between MAI and CAI occured in 25 years stands of Model V 


\section{Financial Analysis of Stands between Models I, II, III, IV and V}

The resulted of the discussion on financial analysis in this section only explain the recapitulation of the resulted of analysis of Models I, II, III, IV and V. Discussion in more detail couldn't be done because of the limitations of the pages. Assumption of production prices in cash flow stands of super teak and solomon teak was Rp.4,000,000 / m3, while sungkai was Rp.1,000,000 / m3. Discount interest used in the financial analysis of each stand was $5 \%, 10 \%$ and $15 \%$. The effort cycle of super teak stands, solomon teak and sungkai was estimated based on the ages of production reaching an optimum point of 25 years. Equivalent Annual Annuity (EAA) value was estimated assuming the total expenditure needs of each decent family was Rp. 3,500,000 / month.

Table 6. Recapitulation of agroforestry and monoculture financial analysis stands with a 5\% discount factor

\begin{tabular}{|c|c|c|c|c|c|c|c|c|c|c|c|}
\hline No. & Stands & $\begin{array}{c}\text { Spacing } \\
(\mathrm{m})\end{array}$ & $\begin{array}{l}\text { Cycle } \\
\text { (year) }\end{array}$ & $\begin{array}{c}\text { MAI } \\
\left(\mathrm{m}^{3} \mathrm{ha}^{-1} \text { year }^{-1}\right)\end{array}$ & $\begin{array}{l}\text { TV } \\
\left(\mathrm{m}^{3}\right) \\
\end{array}$ & $\begin{array}{c}\mathrm{PP} \\
\text { (year) }\end{array}$ & NPV (Rp.) & $\begin{array}{c}\text { Net B/C } \\
\text { Ratio }\end{array}$ & $\begin{array}{l}\text { IRR } \\
(\%) \\
\end{array}$ & EAA (Rp.) & $\begin{array}{c}\text { Effort } \\
\text { Scale (ha) }\end{array}$ \\
\hline 1 & $\begin{array}{c}\text { Teak Super + } \\
\text { Grass }\end{array}$ & $2 \times 10$ & 25 & 6,25 & 156,21 & 6,5 & 186.346 .058 & 3,99 & $28,0 \%$ & 12.122 .078 & 3 \\
\hline 2 & Teak Super & $4 \times 4$ & 25 & 1,32 & 33,10 & 18,5 & $(15.890 .541)$ & 0,72 & $3,0 \%$ & (1.033.703) & -41 \\
\hline 3 & $\begin{array}{c}\text { Teak } \\
\text { Solomon }\end{array}$ & $10 \times 10$ & 25 & 5,07 & 126,67 & 10,4 & 97.546 .242 & 2,38 & $10,3 \%$ & 6.345 .523 & 7 \\
\hline 4 & $\begin{array}{l}\text { Sungkai + } \\
\text { Papaya }\end{array}$ & $2 \times 4$ & 25 & 7,34 & 183,56 & 13,1 & 41.099 .472 & 1,83 & $22,5 \%$ & 2.673 .580 & 16 \\
\hline 5 & Sungkai & $4 \times 4$ & 25 & 4,41 & 110,13 & 18,1 & $(13.141 .863)$ & 0,73 & $3,2 \%$ & $(854.897)$ & -49 \\
\hline
\end{tabular}

\subsection{Model I Financial Analysis}

Table 6 shown that the financial analysis of super teak stands combined with elephant grass with an interest rate of 5\% resulted in an estimated 6.5-year (PP) (PBP) value; Net Present Value (NPV) Rp. 186,346,058, -; Net Benefit / Cost (B / C) Ratio 3.99; Internal Rate of Return (IRR) 28\%; Equivalent Annual Annuity (EAA) Rp. $12,122,078$ and effort scale of 3 ha. Based on the resulted of the analysis, it could be concluded that the exploitation of Model I was feasible because it has a positive NPV value and Net B / C Ratio> 1 which meant that each (Rp.1, -) rupiah invested value would get an income of 3.99 times the value the invested. This statement was reinforced by the IRR value still greater than the Minimum Acceptable Rate (MAR) value of 5\%. The invested capital would return in year 6.5 , then the effort profit would be up to 25 years. The resulted of the EAA analysis mean the value of money that could be paid annually in the same amount of Rp. 12,122,078, - with an interest rate of $5 \%$.

\subsection{Model II Financial Analysis}

Table 6 shown that the financial analysis of monoculture super teak stands with an interest rate of $5 \%$ produced an estimated 18.5-year Pay Back Period (PBP); Net Present Value (NPV) Rp. -15,890,541, -; Net Benefit / Cost (B / C) Ratio 0.72; Internal Rate of Return (IRR) 3\%; Equivalent Annual Annuity (EAA) Rp. -1,033,703, - and effort scale -41 ha. Based on the resulted of the analysis, it was concluded that the effort of Model II was not feasible because it has a negative NPV value and Net B / C Ratio <1 which meant that every (Rp.1, -) rupiah invested value would only return 0.72 times over the value invested or capital does not return to normal. This statement was reinforced by the IRR value was still smaller than the Minimum Acceptable Rate (MAR) of 5\%. The invested capital would return in the 18.5 year. The resulted of a negative EAA analysis mean the value of money that couldn't be paid annually in the same amount of Rp. -1,033,703, - with an interest rate of 5\%.

\subsection{Model III Financial Analysis}

Table 6 shown that the financial analysis of Solomon teak stands with an interest rate of $5 \%$ resulted in an estimation of the Pay Back Period (PBP) of 10.4 years; Net Present Value (NPV) Rp. 97,546,242, -; Net Benefit / Cost (B / C) Ratio 2.38; Internal Rate of Return (IRR) 10\%; Equivalent Annual Annuity (EAA) Rp. 6,345,523 and effort scale of $7 \mathrm{ha}$. Based on the resulted of the analysis, it could be concluded that the effort of Model III was feasible because it has a positive NPV value and Net B / C Ratio> 1 which meant that every (Rp.1, -) rupiah invested value would get an income of 2.38 times the value the invested. This statement was reinforced by a $10 \%$ IRR value that was still greater than the Minimum Acceptable Rate (MAR) value of 5\%. The invested capital would return in the year 10.4, then the effort profit would be up to 25 years. The resulted of the EAA analysis mean the value of money that could be paid annually in the same amount of Rp. 6,345,523, - with an interest rate of $5 \%$. 


\subsection{Model IV Financial Analysis}

Table 6 shown that the financial analysis of sungkai stands combined with papaya with an interest rate of 5\% resulted in an estimated 13.1 year Pay Back Period (PBP) value; Net Present Value (NPV) Rp. 41,099,472, -; Net Benefit / Cost (B / C) Ratio 1.83; Internal Rate of Return (IRR) 22.5\%; Equivalent Annual Annuity (EAA) Rp. 2,673,580, - and effort scale of 16 ha. Based on the resulted of the analysis, it could be concluded that the exploitation of Model IV was feasible because it has a positive NPV value and Net B / C Ratio> 1 which meant that each (Rp.1, -) rupiah invested value would get an income of 1.83 times the value the invested. This statement was strengthened by the IRR value of $22.5 \%$, which was still greater than the Minimum Acceptable Rate (MAR) value of 5\%. The invested capital would return in the next 13.1 years, which was a effort profit of up to 25 years. The resulted of the EAA analysis mean the value of money that could be paid annually in the same amount of Rp. 2,673,580, - with an interest rate of $5 \%$.

\subsection{Model V Financial Analysis}

Table 6 shown that the financial analysis of monoculture sungkai stands with an interest rate of 5\% produced an estimated 18.1 year Pay Back Period (PBP) value; Net Present Value (NPV) Rp. -13.141,863, -; Net Benefit / Cost (B / C) Ratio 0.73; Internal Rate of Return (IRR) 3.2\%; Equivalent Annual Annuity (EAA) Rp. -854,897, and effort scale -49 ha. Based on the resulted of the analysis, it was concluded that the effort of Model V was not feasible because it has a negative NPV value and Net B / C Ratio <1 which meant that every (Rp.1, -) rupiah invested value would only return 0.73 times over the value invested or capital does not return to normal. This statement was reinforced by the IRR value was still smaller than the Minimum Acceptable Rate (MAR) of 5\%. The invested capital would return in the year 18.1. The resulted of a negative EAA analysis mean the value of money that couldn't be paid annually in the same amount of Rp. $-854,897$, - with an interest rate of $5 \%$.

\subsection{Recapitulation of Stand Financial Analysis}

The conclusions obtained from the resulted of the recapitulation of financial analysis that was cultivated in agroforestry and monoculture with a 5\% discount factor, namely the exploitation of Model I, Model III and Model IV were feasible because they have an IRR value higher than MAR 5\% and Net B / C Ratio higher from 1. Model II and Model V were not feasible because they have an IRR value lower than MAR 5\% and Net B / C Ratio lower than 1 . The optimum production of all models was reached at the ages of 25 years. The highest MAI was achieved in Model IV of $7.34 \mathrm{~m} 3 \mathrm{ha}-1$ year-1 and the total volume was $183.56 \mathrm{~m}^{3} \mathrm{ha}^{-1}$ year-1, while the lowest MAI was achieved in Model II of $6.25 \mathrm{~m}^{3}$ ha-1 year-1 and the total volume was $33.10 \mathrm{~m}^{3}$ ha- 1 year- 1 . Based on the analysis of effort scale results, Model I could be the first choice that was most feasible because it has the lowest effort scale value, while Model V was the least feasible option to be cultivated because it has the highest scale of effort. The NPV value of Model I, Model III and IVshown a positive value of Rp. 186,346,058, -; Rp.97,546,242, - and Rp.41,099,472, -, while Model II and Model IV showed a negative value of Rp.-15,590,541 and Rp.13,141,863.

Table 7. Recapitulation of sensitivity analysis at interest rate of 5\%,10\% and $15 \%$ by cost raise to $10 \%$

\begin{tabular}{|c|c|c|c|c|c|c|c|c|}
\hline \multirow{2}{*}{ Model } & \multirow{2}{*}{ Stands } & \multicolumn{3}{|c|}{ NPV (x Rp.1000) } & \multicolumn{3}{|c|}{ Net B/C Ratio } & \multirow{2}{*}{ IRR } \\
\hline & & $5 \%$ & $10 \%$ & $15 \%$ & $5 \%$ & $10 \%$ & $15 \%$ & \\
\hline I & Teak Super + King Grass & 166.475 & 48.952 & 11.256 & 3,34 & 1,882 & 1,23854 & $19,0 \%$ \\
\hline II & Teak Super & $(23.554)$ & $(36.546)$ & $(37.821)$ & 0,62 & 0,260 & 0,10907 & $2,1 \%$ \\
\hline III & Teak Solomon & 83.990 & $(4.642)$ & $(30.276)$ & 2,08 & 0,924 & 0,40829 & $9,5 \%$ \\
\hline IV & Sungkai + Papaya & 41.099 & 8.992 & $(1.003)$ & 1,83 & 1,222 & 0,97159 & $14,2 \%$ \\
\hline V & Sungkai & $(20.063)$ & $(32.924)$ & $(34.636)$ & 0,62 & 0,257 & 0,10777 & $2,3 \%$ \\
\hline
\end{tabular}

Table 8. Recapitulation of sensitivity snalysis at interest rate of 5\%,10\% and $15 \%$ by benefit decrease to $10 \%$

\begin{tabular}{|c|c|c|c|c|c|c|c|c|}
\hline \multirow{2}{*}{ Model } & \multirow{2}{*}{ Stands } & \multicolumn{3}{|c|}{ NPV (x Rp.1000) } & \multicolumn{3}{|c|}{ Net B/C Ratio } & \multirow{2}{*}{ IRR } \\
\hline & & $5 \%$ & $10 \%$ & $15 \%$ & $5 \%$ & $10 \%$ & $15 \%$ & \\
\hline 1 & Teak Super + King Grass & 147.840 & 42.744 & 9.091 & 3,28 & 1,84 & 1,21 & $18,4 \%$ \\
\hline 2 & Teak Super & $(21.965)$ & $(33.417)$ & $(34.455)$ & 0,61 & 0,26 & 0,11 & $2,1 \%$ \\
\hline 3 & Teak Solomon & 74.235 & $(4.962)$ & (27.803) & 2,05 & 0,91 & 0,40 & $9,4 \%$ \\
\hline 4 & Sungkai + Papaya & 35.908 & 7.320 & (1.533) & 1,80 & 1,20 & 0,95 & $13,6 \%$ \\
\hline 5 & Sungkai & (18.749) & (30.113) & $(31.557)$ & 0,61 & 0,25 & 0,11 & $2,2 \%$ \\
\hline
\end{tabular}




\section{Conclusion}

It's concluded that by 5\% discount factor, Model I, Model III and Model IV were feasible to be cultivated which more profitable than Model II and Model V. The optimum production of all models was reached at the ages of 25 years, so we should take its value to be the planting rotation as the highest economic value. The highest MAI was achieved in Model IV which had highest production, while the lowest MAI was achieved in Model II. Based on the analysis of effort scale shown that Model I could be the best choice and most feasible than other because it had the lowest effort scale value, while Model $\mathrm{V}$ was the least feasible option to be cultivated because it has the highest scale of effort, so if we want to planting such types Model would better to have 16 ha maximum wide area. Model I, Model III and IV shown the NPV positive value, while Model II and Model IV shown the negative value which not feasible to be cultivated. We suggested to give between $9,4 \%$ to $19 \%$ maximum interest rate to the farmers' financial needs, then its level of survival interest rate would be managed to the selected types plantation correctly.

\section{Aknowledgements}

During the conduct of research and research compilation many parties have helped, so we convey our sincere gratitude and appreciation to all reviewers who gave many opinions and final suggestions for writing this research.

\section{References}

Barkin, D., \& Fuente, M. (2013). Community forest management: Can the green economy contribute to environmental justice? Natural Resources Forum, 37(3), 200-210. https://doi.org/10.1111/1477-8947.12010

Basu, J. (2014). Agroforestry, climate change mitigation and livelihood security in India. Journal Forest Science, 44(Suppl 1), S11. https://doi.org/10.1186/1179-5395-44-S1-S11

Bernetti, I., Ciampi, C., Fagarazzi, C., \& Sacchelli, S. (2011). The evaluation of forest crop damages due to climate change. An application of Dempster-Shafer method. J. For Economics, 17(3), 285-297. https://doi.org/10.1016/j.jfe.2011.04.005

Buongiorno, J., \& Zhu, S. (2014). Assessing the impact of planted forests on the global forest economy. Journal Forest Science, 44(Suppl 1), S2. https://doi.org/10.1186/1179-5395-44-S1-S2

Dave, R., Tompkins, E. L., \& Schreckenberg, K. (2017). Forest ecosystem services derived by smallholder farmers in northwestern Madagascar: Storm hazard mitigation and participation in forest management. Journal Forest Policy and Economics, 84, 72-82. https://doi.org/10.1016/j.forpol.2016.09.002

Farshad Keivan, B., \& Omid Ghaffarzadeh, M. (2018). Effects of tree diameter and some working conditions on residual stump height following selective logging - short communication. Journal Forest Science, 64(No. 2), 91-95. https://doi.org/10.17221/100/2017-JFS

Gardingen, P. R., McLeish, M. J., Phillips, P. D., Fadilah, D., Tyrie, G., Yasman, I., \& Gatot Subroto, J. (2003). Financial and ecological analysis of management options for logged-over Dipterocarp forests in Indonesian Borneo (Vol. 183). https://doi.org/10.1016/S0378-1127(03)00097-5

Guzmán, N., Moya, R., \& Murillo, O. (2017). Evaluation of bent trees in juvenile teak (Tectona grandis L.f.) plantations in Costa Rica: Effects on tree morphology and wood properties. Journal Forest, 8(3), 79. https://doi.org/10.3390/f8030079

Iskandar, J. (2016). Responses to environmental and socio-economic changes in the Karangwangi traditional agroforestry system, South Cianjur, West Java. Journal Biodiversity, 17(1), 332-341. https://doi.org/10.13057/biodiv/d170145

Jenkins, R. K. B., \& Roettcher, K. (n. d.). The influence of stand age on wildlife habitat use in exotic teak tree Tectona grandis plantations.

Khasanah, N., Perdana, A., Rahmanullah, A., Manurung, G., Roshetko, J. M., \& Van Noordwijk, M. (2015). Intercropping teak (Tectona grandis) and maize (Zea mays): Bioeconomic trade-off analysis of agroforestry management practices in Gunungkidul, West Java. Agroforestry System, 89(6), 1019-1033. https://doi.org/10.1007/s10457-015-9832-8

Kupčák, V. (2012). Elementary financial analysis of the forests of the Czech Republic, state enterprise. Journal Forest Science, 51(3), 127-140. https://doi.org/10.17221/4551-JFS

Lahjie, A. M., Nouval, B., Annisa, A. L., Ruslim, Y., \& Kristiningrum, R. (2019). Economic valuation from direct use of mangrove forest restoration in Balikpapan Bay, East Kalimantan, Indonesia. Journal F1000 
Research. https://doi.org/10.12688/f1000research.17012.2

Lahjie, A. M., Simarangkir, B. D. A. S., Kristiningrum, R., Ruslim, Y., \& Lepong, A. (2018). Financial analysis of dipterocarp log production and rubber production in the forest and land rehabilitation program of Sekolaq Muliaq, West Kutai District, Indonesia. Journal Biodiversity, 19(3), 707-716. https://doi.org/10.13057/biodiv/d190301

Linger, E. (2014). Agro-ecosystem and socio-economic role of homegarden agroforestry in Jabithenan District, North-Western Ethiopia: Implication for climate change adaptation. Journal SpringerPlus, 3(1), 154. https://doi.org/10.1186/2193-1801-3-154

Luedeling, E., Kindt, R., Huth, N. I., \& Koenig, K. (2014). Agroforestry systems in a changing climate - challenges in projecting future performance. Current Opinion in Environmental Sustainability, 6, 1-7. https://doi.org/10.1016/j.cosust.2013.07.013

Matveev, S., Milenin, A., \& Timashchuk, D. (2018). The effects of limiting climate factors on the increment of native tree species (Pinus sylvestris L., Quercus robur L.) of the Voronezh region. Journal Forest Science 64(10), 427-434. https://doi.org/10.17221/36/2018-JFS

Mohammad, H., Majid, L., \& Soleiman, M. L. (2018). Estimating the economic life of forest machinery using the cumulative cost model and cost minimization model in Iranian Caspian forests. Journal Forest Science, 64(5), 216-223. https://doi.org/10.17221/133/2017-JFS

Moya, R., \& Marín, J. D. (2011). Grouping of Tectona grandis (L.f.) clones using wood color and stiffness. Journal New Forest, 42(3), 329-345. https://doi.org/10.1007/s11056-011-9255-y

Mulatu, T., Bastos, R., Santos, M., Sousa, J. P., da Silva, P. M., \& Cabral, J. A. (2016). Do the passerine traits' dynamic patterns indicate the ecological status of agro-forestry ecosystems? a modelling approach for "Montado" management assessments. Journal Global Ecology and Conservation, 8, 154-169. https://doi.org/10.1016/j.gecco.2016.09.001

Murtinah, V., Ruchaemi, A., \& Ruhiyat, D. (2015). Pertumbuhan hutan tanaman jati (Tectona grandis Linn.f.).

Narita, D., Lemenih, M., Shimoda, Y., \& Ayana, A. N. (2018). Economic accounting of Ethiopian forests: A natural capital approach. Journal Forest Policy and Economics, 97, 189-200. https://doi.org/10.1016/j.forpol.2018.10.002

Panjaitan, S. (2014). Prospek dan teknik budidaya sungkai.

Pramono, A. A., Fauzi, M. A., \& Pramono, A. A. (2010). Pengelolaan hutan jati rakyat: panduan lapangan untuk petani.

Reed, J., van Vianen, J., Foli, S., Clendenning, J., Yang, K., MacDonald, M., \& Sunderland, T. (2017). Trees for life: The ecosystem service contribution of trees to food production and livelihoods in the tropics. Journal Forest Policy and Economics, 84, 62-71. https://doi.org/10.1016/j.forpol.2017.01.012

Ruslim, Y. (2011). Penerapan reduced impact logging menggunakan monocable winch (pancang tarik).

Ruslim, Y. (2016). Stand damage due to mono-cable winch and bulldozer yarding in a selectively logged tropical forest. Journal Biodiversity, 17(1), 222-228. https://doi.org/10.13057/biodiv/d170132

Sandalayuk, D., Lahjie, A. M., Simarangkir, B. D. A. S., \& Ruslim, Y. (2019). Analysis growth and makro hara elements Jabon (Anthocephalus cadamba), jati (Tectona grandis) in Gorontalo. IOP Conference Series: Earth and Environmental Science, 270, 012045. https://doi.org/10.1088/1755-1315/270/1/012045

Siregar, U. J., Narendra, B. H., Suryana, J., Siregar, C. A., \& Weston, C. (2017). Evaluation on community tree plantations as sustainable source for rural bioenergy in Indonesia. IOP Conference Series: Earth and Environmental Science, 65, 012019. https://doi.org/10.1088/1755-1315/65/1/012019

Sunderland, T., Abdoulaye, R., Ahammad, R., Asaha, S., Baudron, F., Deakin, E., \& Van Vianen, J. (2017). A methodological approach for assessing cross-site landscape change: understanding socio-ecological systems. Journal Forest Policy and Economics, 84, 83-91. https://doi.org/10.1016/j.forpol.2017.04.013

Van Gardingen, P. R., McLeish, M. J., Phillips, P. D., Fadilah, D., Tyrie, G., \& Yasman, I. (2003). Financial and ecological analysis of management options for logged-over Dipterocarp forests in Indonesian Borneo. Journal Forest Ecology and Management, 183(1-3), 1-29. https://doi.org/10.1016/S0378-1127(03)00097-5 
Vanzetti, N., Broz, D., Corsano, G., \& Montagna, J. M. (2018). An optimization approach for multiperiod production planning in a sawmill. Journal Forest Policy and Economics, 97, 1-8. https://doi.org/10.1016/j.forpol.2018.09.001

Verhaegen, D., Fofana, I. J., Logossa, Z. A., \& Ofori, D. (2010). What is the genetic origin of teak (Tectona grandis L.) introduced in Africa and in Indonesia? Tree Genetics \& Genomes, 6(5), 717-733. https://doi.org/10.1007/s11295-010-0286-X

Wahyudi, Z. M., \& Russel, M. A. (2012). Growth and yield analysis of Peronema canescens Jack.

Wanneng, P., \& Ozarska, B. (2014). Physical properties of Tectona grandis grown in. Journal Tropical Forest Science, 9 .

Winarni, B. (2017). Tengkawang cultivation model in community forest using agroforestry systems in West Kalimantan, Indonesia. Journal Biodiversity, 18(2), 765-772. https://doi.org/10.13057/biodiv/d180246

Zahabu, E., Raphael, T., Chamshama, S. A. O., Iddi, S., \& Malimbwi, R. E. (2015). Effect of spacing regimes on growth, yield, and wood properties of Tectona grandis at Longuza forest plantation, Tanzania. Journal Forest Research, 1-6. https://doi.org/10.1155/2015/469760

\section{Copyrights}

Copyright for this article is retained by the author(s), with first publication rights granted to the journal.

This is an open-access article distributed under the terms and conditions of the Creative Commons Attribution license (http://creativecommons.org/licenses/by/4.0/). 